\title{
ANALISIS JALUR DISTRIBUSI INDUSTRI GULA DENGAN MENGGUNAKAN METODE INPUT OUTPUT
}

\author{
Riski Nur I.D. \\ Jurusan Matematika FMIPA Universitas Brawijaya Malang \\ Email:ky2_zahra@yahoo.com
}

\begin{abstract}
The model of sugar industry distribution channel consist of sugarcane farmers, suppliers, millers and distributors. In this research, we analyze the distribution channel of sugar industry model by using inputoutput method. The analysis is used to know Backward Linkages and Forward Linkages of intersector. The linkages can identify key sector that have a big influence on the development of other sectors. The result of model analysis show that there is no sector that has high Backward and Forward Linkages, so there is no key sector in sugar industry distribution channel.
\end{abstract}

Keywords: distribution channel, input-output method, backward linkages, forward linkages, key sector

Gula merupakan salah satu dari sembilan bahan pokok yang dikonsumsi oleh masyarakat.Selain dikonsumsi secara langsung (konsumsi akhir), gula juga merupakan bahan baku bagi banyak industri (input antara) yaitu pada industri makanan dan minuman yang berperan sebagai bahan pemanis maupun bahan pengawet untuk sebagian pangan olahan. Dari waktu ke waktu perkembangan industri gula di Indonesia selalu menarik untuk dibahas, mulai masa kejayaan Indonesia sebagai negara pengekspor gula terbesar hingga keterpurukan produksi gula yang mengharuskan Indonesia menjadi negara pengimpor gula sejak awal tahun 1990 hingga saat ini dengan jumlah permintaan yang semakin tinggi. Secara historis, industri gula merupakan salah satu industri perkebunan tertua dan terpenting yang ada di Indonesia.

Aktivitas ekonomi, industri gula jugamerupakan industri yang potensial dalam meningkatkan perekonomian nasional di Indonesia dan memiliki peluang sebagai salah satu motor ekonomi di masa depan. Perkembangan dari industri gula tersebut akan berimbas pada perkembangan industri yang lainnya. Hal ini akan memberikan dampak ganda yang cukup signifikan secara nasional terhadap penciptaan output, pendapatan, dan tenaga kerja mengingat gula merupakan suatu komoditi pangan yang penggunaannya sangat luas. Oleh karena itu, pembangunan industri gula harus dilihat secara komprehensif dalam kaitannya dengan pembangunan industri lain, sebagai industri pendorong maupun penarik industri lain dan menyerap tenaga kerja di daerah pedesaan maupun perkotaan. Industri gula perlu melakukan berbagai perubahan dan penyesuaian guna meningkatkan produktivitas, dan efisiensi, sehingga menjadi industri yang kompetitif, mempunyai nilai tambah yang tinggi, dan memberi tingkat kesejahteraan yang memadai bagi para pelakunya, khususnya petani (Khudori, 2005).

Pertumbuhan industri gula memiliki keterkaitan yang sangat erat dengan pengembangan sektor pertanian. Industri gula sebagian besar berada pada wilayah yang mempunyai lahan pertanian yang relatif masih luas dalam penanaman tebu sehingga kuantitas produksi gula yang dihasilkan akan ikut meningkat. Melalui analisis keterkaitan jalur distribusi industri gula dapat dilihat keterkaitan ke belakang (backward linkages) terhadap bahan baku yang berhubungan dengan petani tebu dan keterkaitan ke depan (forward linkages) dengan industri pengolahan. Industri gula memiliki keterkaitan ke belakang yang cukup tinggi, $81 \%$ terkonsentrasi pada tiga industri utama, yaitu industri tebu, industri perdagangan dan industri tanaman tebu. Sementara untuk keterkaitan ke depan tergolong lemah, $90 \%$ terkonsentrasi pada tiga industri utama, yaitu industri makanan, industri minuman dan industri tepung (Khudori, 2005).

Para ahli menggunakan analisis keterkaitan tersebut yaitu keterkaitan ke belakang (backward linkages) dan keterkaitan ke depan (forward linkages) untuk menganalisa dan menentukan sektor-sektor kunci (key sector) yang perlu untuk dikembangkan dalam jalur distribusi industri gula. Sektor kunci memiliki pengaruh yang besar terhadap sektor-sektor 
yang lain karena sektor kunci tersebut memiliki kemampuan menjadi lokomotif bagi berkembangnya sektor-sektor lain. Oleh karena itu, sektor kunci yang memiliki keterkaitan tinggi dengan sektor yang lain perlu untuk mendapat perhatian lebih sehingga apabila sektor kunci tersebut mengalami pertumbuhan, maka sektor yang memiliki keterkaitan terhadap sektor kunci ini juga akan mengalami pertumbuhan.

Model input output atau biasa disingkat I-O merupakan suatu cara untuk menggambarkan aliran output dari suatu industri ke industri yang lain dan dari produsen ke konsumen akhir (Sumodiningrat, et al., 1991). Analisis ini juga memberikan gambaran tentang aliran barang, jasa dan input antar sektor sekaligus dapat digunakan sebagai alat untuk mengetahui pengaruh suatu perubahan situasi ekonomi atau kebijakan ekonomi (Boediono, 1993).

Untuk jalur distribusi, analisis dengan menggunakan metode input output dapat memberikan gambaran tentang aliran kegiatan dari bahan baku menjadi bahan jadi. Selain itu, kegunaan dari model tersebut juga untuk menggambarkan kegiatan dari produsen hingga ke konsumen akhir dalam jalur distribusi.

\section{METODE}

Data yang digunakan berupa data primer dari hasil wawancara, baik individu ataupun kelompok. Tempat penelitian dilakukan di beberapat empat yang berada di lingkup wilayah Kabupaten Malang dengan obyek penelitian adalah: (1) Kelompok tani tebu; (2) Koperasi agroniaga sebagai pengepul tebu; (3) Pabrik gula sebagai penggiling tebudan.(4) Distributor gula.
Penelitian ini menggunakan model input output atau biasa disingkat I-O yaitu suatu cara untuk menggambarkan aliran output dari suatu industri ke industri yang lain dan dari produsen ke konsumen akhir (Sumodiningrat, et al., 1991). Analisis ini juga memberikan gambaran tentang aliran barang, jasa dan input antar sektor sekaligus dapat digunakan untuk mengetahui pengaruh suatu perubahan situasi ekonomi atau kebijakan ekonomi (Boediono, 1993).

Tabel input-output pada dasarnya terdiri dari beberapa tabel yang dituangkan dalam suatu sistem kuadran. Pembagian ini sangat penting untuk dapat memahami saling keterkaitan antar industri dalam perekonomian. Pembagian kuadran tersebut terlihat pada tabel di bawah ini:

Total output industri i $\left(x_{i}\right)$ adalah jumlah output industri i yang digunakan sebagai input antara oleh industri $\mathrm{j}(j=1,2, \ldots, n)$ ditambah dengan Permintaan Akhir industri ke-i, yang dirumuskan dalam bentuk sebagai berikut:

$$
\begin{gathered}
x_{1}=x_{11}+x_{12}+\cdots+x_{1 n}+d_{1} \\
x_{2}=x_{21}+x_{22}+\cdots+x_{2 n}+d_{2} \\
\vdots \\
x_{n}=x_{n 1}+x_{n 2}+\cdots+x_{n n}+d_{n}
\end{gathered}
$$

Secara umum, persamaan (1) dapat dirumuskan kembali menjadi:

$$
x_{i}=\sum_{j=1}^{n} x_{i j}+d_{i} \text { untuk } i=1,2, \ldots, n
$$

Tabel 1. Kerangka Tabel Input Output

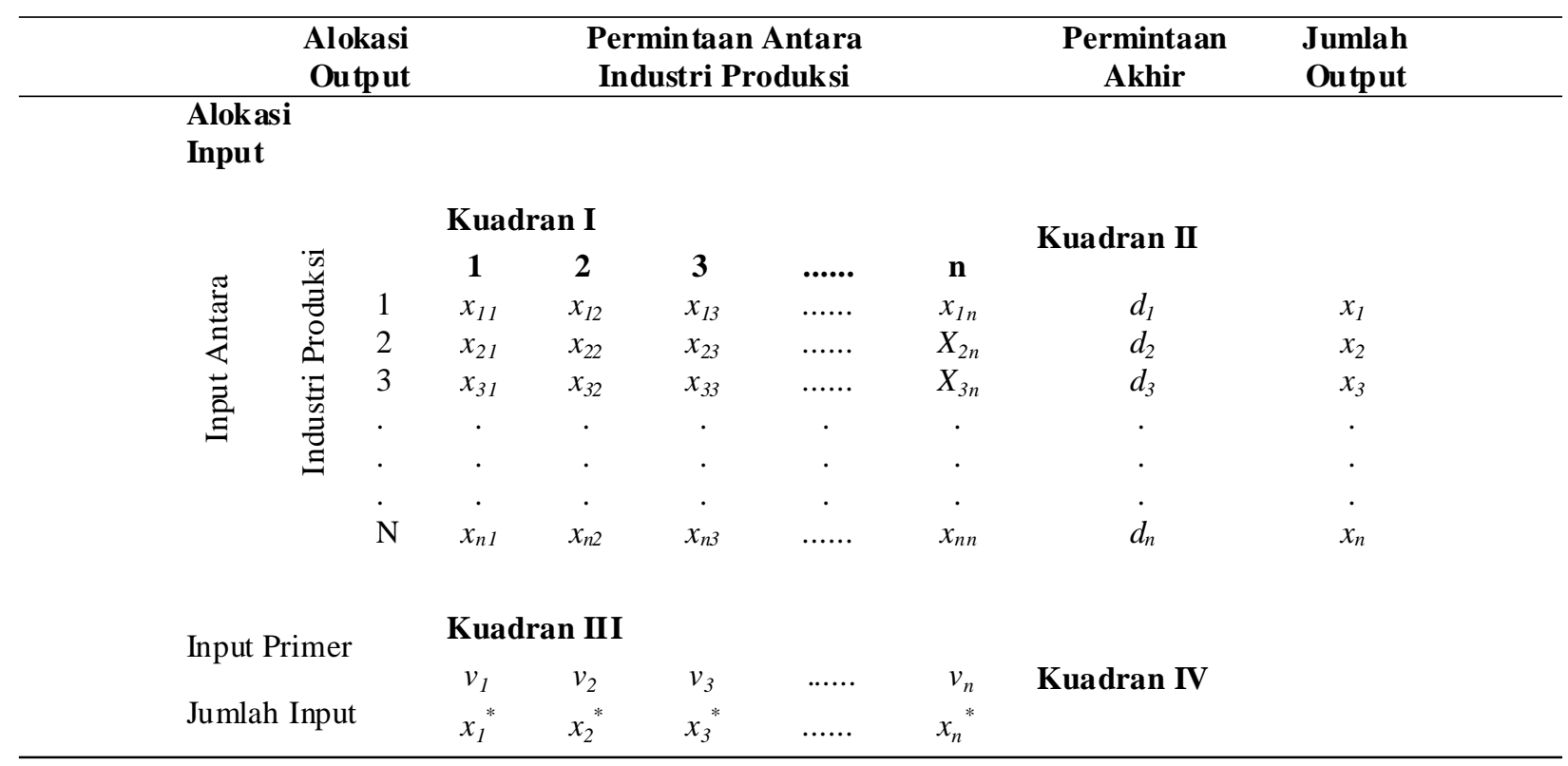


di mana:

$x_{i j}=$ Output industri $i$ yang digunakan sebagai input industri $j$

$d_{i}=$ Permintaan akhir terhadap industri $i$

$x_{i}=$ Total output industri $i$.

Sementara itu, total input suatu industri adalah jumlah seluruh input antaraditambah dengan input primer dan dirumuskan dalam bentuk:

$$
\begin{gathered}
x_{1}{ }^{*}=x_{11}+x_{21}+\cdots+x_{n 1}+v_{1} \\
x_{2}{ }^{*}=x_{12}+x_{22}+\cdots+x_{n 2}+v_{2} \\
\vdots \\
x_{n}{ }^{*}=x_{1 n}+x_{2 n}+\cdots+x_{n n}+v_{n}
\end{gathered}
$$

atau dalam bentuk persamaan umum dapat dituliskan sebagai:

$x_{j}^{*}=\sum_{i=1}^{n} x_{i j}+v_{j} \quad$ untuk $j=1,2, \ldots ., n$

di mana:

$x_{i j}=$ Output industri $i$ yang digunakan sebagai input oleh industri $j$.

$x_{j}{ }^{*}=$ Total input industri $j$.

$v_{j}=$ Input Primer (nilai tambah) industri $j$.

Misalkan adalah koefisien input antara di mana koefisien tersebut melambangkan jumlah input dari industri ke-i yang diperlukan untuk memproduksi satu unit output di industri ke-j, sehingga dapat dituliskan sebagai berikut:

$$
a_{i j}=\frac{x_{i j}}{x_{j}}
$$

Dari persamaan (5) diperoleh

$x_{i j}=a_{i j} \cdot x_{j}$

(Nazara, 2005).

Kemudian substitusikan persamaan (5) ke persamaan (2), maka diperoleh

$x_{i}=\sum_{j=1}^{n} a_{i j} x_{j}+d_{i}$

Dalam notasi matriks dapat ditulis sebagai berikut

$x=A x+d$

Dengan memindahkan bentuk $A x$ ke kiri maka didapatkan
$x-A x=d$

$(1-A) x=d$

Selanjutnya, penyelesaian dari persamaan (9) adalah

$x=(I-A)^{-1} d$

di mana sering disebut sebagai matriks invers Leontief atau disebut juga sebagai matriks pengganda output (Leon, 1998). Bentuk tersebut dinotasikan dalam matriks yang dapat dituliskan sebagai berikut:

$\alpha=\left[\begin{array}{c}\alpha_{11} \alpha_{12} \ldots \alpha_{1 n} \\ \alpha_{21} \alpha_{22} \ldots \alpha_{2 n} \\ \vdots \\ \alpha_{n 1} \alpha_{n 2} \ldots \alpha_{n n}\end{array}\right]$

Matriks tersebut yang akan digunakan untuk menganalisis keterkaitan ke belakang (Backward Lingkages) dan keterkaitan ke depan (Forward Lingkages) dalam jalur distribusi industri gula. Keterkaitan ke belakang (Backward Lingkages) merupakan alat analisis untuk mengetahui derajat keterkaitan suatu sektor terhadap sektor-sektor lain yang menyumbang input kepadanya. Sementaraia itu, keterkaitan ke depan (Forward Lingkages) merupakan alat analisis untuk mengetahui derajat keterkaitan antara suatu sektor yang menghasilkan output untuk digunakan sebagai input bagi sektor-sektor lain.

\section{Analisis Keterkaitan}

Metode input output dapat digunakan untuk mengukur keterkaitan atau tingkat saling ketergantungan antar sektor. Keterkaitan ini menunjukkan sejauh mana pertumbuhan atau perubahan suatu sektor mempengaruhi atau dipengaruhi oleh pertumbuhan atau perubahan sektor-sektor lainnya. Dalam suatu proses industri, input berupa bahan baku diubah menjadi produk sebagai output-nya. Pengadaan input akan memperlihatkan adanya keterkaitan kebelakang antara bahan baku dengan industri pengolahan. Input bahan baku untuk suatu sektor industri diperoleh dari beberapa sumber, diantaranya adalah dari sektor itu sendiri atau dari sektor lain. Output yangdihasilkan selain digunakan sebagai konsumsi masyarakat dan oleh sektor industri pengolahan juga merupakan input bagi industri lainnya dan sektor industri itu sendiri, jika mungkin untuk diekspor.

Keterkaitan antar sektor ini dapat diukur dengan menggunakan dua metode, yaitu metode Rasmussen 
dan metode Chenery-Watanabe. Metode Rasmussen menggunakan matriks invers Leontief dalam proses perhitungannya, sedangkan metode Chenery-Watanabe menggunakan matriks koefisien input dan output. Metode Chenery-Watanabe tersebut hanya mengukur dampak keterkaitan langsung antar sektor saja sehingga metode Rasmussen lebih banyak digunakan oleh beberapa peneliti karena metode ini tidak hanya mengukur keterkaitan langsung tetapi juga keterkaitan tak langsung antar sektor (Zhou, 2011).

Jenis keterkaitan yang akan dianalisis dalam penelitian ini adalah keterkaitan ke belakang (Backward Lingkages) dan keterkaitan ke depan (Forward Lingkages) berdasarkan metode Rasmussen. Keterkaitan ke belakang (Backward Lingkages) merupakan alat analisis untuk mengetahui derajat keterkaitan suatu sektor terhadap sektor-sektor lain yang menyumbang input kepadanya. Sementara itu, keterkaitan ke depan (Forward Lingkages) merupakan alat analisis untuk mengetahui derajat keterkaitan antara suatu sektor yang menghasilkan output untuk digunakan sebagai input bagi sektor-sektor lain (Kuncoro, 2001).

\section{Analisis Keterkaitan ke Belakang (Backward Linkages)}

Terjadinya peningkatan produksi suatu industri akan menimbulkan dampak terhadap permintaan input. Dalam jalur distribusi industri gula, analisis keterkaitan ke belakang (Backward Linkages) dapat digunakan untuk melihat derajat keterkaitan suatu sektor terhadap sektor lain yang menyumbangkan input kepada sektor tersebut.

Berdasarkan metode Chenery-Watanabe, indeks keterkaitan ke belakang (Backward Linkages) merupakan jumlah kolom dari matriks koefisien input yang didefinisikan sebagai berikut:

$$
B L^{C W}=\sum_{i=1}^{n} \frac{x_{i j}}{x_{j}}=\sum_{i=1}^{n} a_{i j}
$$

dengan

$$
\begin{array}{ll}
B L_{j}^{C W} & \begin{array}{l}
\text { adalah keterkaitan ke belakang sektor- } j \text { untuk } \\
\text { metode Chenery-Watanabe }
\end{array} \\
a_{i j} & \begin{array}{l}
\text { adalah matriks koefisien input dari sektor- } i \\
\text { ke sektor- } j \text { (Kula, 2008). }
\end{array}
\end{array}
$$

Sementara itu, menurut model Rasmussen, Indeks keterkaitan ke belakang (Backward Linkages) disebut juga sebagai indeks daya penyebaran yaitu efek relatif dari kenaikan output suatu industri terhadap peningkatan output industri lain. Indeks keterkaitan ke belakang (Backward Linkages) ini didefinisikan sebagai berikut,

$$
B L_{j}=\frac{\sum_{i=1}^{n} \alpha_{i j}}{\left(\frac{1}{n}\right) \sum_{i=1}^{n} \sum_{j=1}^{n} \alpha_{i j}}
$$

di mana:

$B L_{j}$ adalah indeks keterkaitan ke belakang (Backward Linkages) industri $\mathrm{j}$

$n$ adalah jumlah industri

$\alpha_{i j}$ adalah elemen baris-i kolom-j dari matriks invers leontief (Zhou, 2011).

Jika lebih dari satu, maka daya penyebaran dari industri-j berada di atas rata-rata penyebaran seluruh kegiatan. Dengan kata lain, apabila lebih dari satu, maka daya penyebaran dari industri-j tinggi terhadap sektor-sektor yang lain. Sementara itu, jika kurang dari satu, maka daya penyebaran dari industri-j di bawah rata-rata penyebaran industri lainnya. Dengan kata lain, apabila kurang dari satu, maka daya penyebaran dari industri-j rendah terhadap sektor-sektor yang lain (Hermawan, 2006).

\section{Analisis Keterkaitan ke Depan (Forward Linkages)}

Peningkatan output suatu industri memberikan dampak terhadap pertumbuhan tarhadap industriindustri yang lain. Dalam jalur distribusi industri gula, analisis keterkaitan ke depan (Forward Linkages) dapat digunakan untuk melihat derajat keterkaitan suatu sektor yang menghasilkan output untuk digunakan sebagai input bagi sektor yang lain.

Berdasarkan metode Chenery-Watanabe, indeks keterkaitan ke depan (Forward Linkages) merupakan jumlah baris dari matriks koefisien output yang didefinisikan sebagai berikut:

$$
F L^{C W}{ }_{i}=\sum_{j=1}^{n} \frac{x_{i j}}{x_{i}}=\sum_{j=1}^{n} b_{i j}
$$

dengan

$F L^{C W}{ }_{i}$ adalah keterkaitan ke depan sektor- $i$ untuk metode Chenery-Watanabe

$b_{i j} \quad$ adalah matriks koefisien output dari sektor- $i$ ke sektor-j (Kula, 2008).

Sementara itu, menurut model Rasmussen, Indeks keterkaitan ke depan (Forward Linkages) disebut juga sebagai indeks daya kepekaan yaitu efek relatif dari peningkatan output suatu industri tertentu sebagai penyedia sumber daya bagi industri yang lain. Indeks 
keterkaitan ke depan (Forward Linkages) didefinisikan sebagai berikut:

$F L_{i}=\frac{\sum_{j=1}^{n} \alpha_{i j}}{\left(\frac{1}{n}\right) \sum_{i=1}^{n} \sum_{j=1}^{n} \alpha_{i j}}$

di mana:

$F L_{i}$ adalah indeks keterkaitan ke depan (Forward Linkages) industri i

$n \quad$ adalah jumlah industri

$\alpha_{i j}$ adalah elemen baris-i kolom- $j$ dari matriks invers leontief

(Zhou, 2011).

Jika lebih dari satu, maka daya kepekaan dari industri-i berada di atas rata-rata kepekaan seluruh kegiatan. Dengan kata lain, apabila lebih dari satu, maka daya kepekaan dari industri-i tinggi terhadap sektor-sektor yang lain. Sementara itu, jika kurang dari satu, maka daya kepekaan dari industri-i di bawah rata-rata kepekaan industri lainnya. Dengan kata lain, apabila kurang dari satu, maka daya kepekaan dari industri-i rendah terhadap sektor-sektor yang lain (Hermawan, 2006).

\section{Penentuan Sektor Kunci (Key Sector) dengan Menggunakan Analisis Keterkaitan}

Dalam metode input output dapat diidentifikasi sektor kunci (key sector) yang memiliki keterkaitan ke belakang (Backward Linkages) yang tinggi dan keterkaitan ke depan (Forward Linkages) yang tinggi. Sektor yang mempunyai keterkaitan ke depan tinggi menunjukan sektor tersebut mempunyai daya dorong yang cukup kuat untuk meningkatkan pertumbuhan sektor hilir, sedangkan sektor yang mempunyai keterkaitan ke belakang yang tinggi menunjukkan bahwa sektor tersebut mempunyai daya tarik tinggi terhadap pertumbuhan sektor hulu. Sektor kunci sangat besar peranannya dalam jalur distribusi dan dapat ditentukan berdasarkan indeks keterkaitan ke belakang dan indeks keterkaitan ke depan. Suatu sektor apabila dan, maka sektor tersebut merupakan sektor kunci (key sector) atau dapat dikatakan sebagai leading sector, karena mempunyai tingkat keterkaitan ke depan dan keterkaitan ke belakang yang tinggi (Didit dan Devi, 2008).

\section{Jalur Distribusi}

Menurut American Supply Chain Association jalur distribusi bisa diartikan sebagai seluruh kegiatan yang terlibat dalam proses produksi dan pengiriman produk akhir atau jasa antar produsen satu ke produsen yang lain atau konsumen yang satu ke konsumen yang lain, sehingga pemilihan pasangan yang strategis menjadi penting untuk relasi kerjasama antar perusahaan inti untuk membentuk aliansi dengan perusahaan yang lain (Wu, 2007).

Jalur distribusi dapat juga didefinisikan suatu rantai atau jaringan dari suatu sistem organisasi, manusia, teknologi informasi atau sumberdaya yang melibatkan perpindahan produk atau jasa dari produsen ke konsumen. Jalur distribusi juga dapat dikatakan sebagai suatu aktivitas yang mengelola bahan baku menjadi bahan jadi yang didistribusikan dari produsen ke konsumen akhir (Anonimus, 2012).

\section{HASIL DAN PEMBAHASAN}

\section{Jalur Distribusi Industri Gula}

Jalur distribusi merupakan suatu aktivitas mengelola bahan baku menjadi bahan jadi yang didistribusikan dari produsen hingga ke konsumen akhir. Dalam jalur distribusi industri gula ini, kegiatan usaha tani tebu dan proses pengolahan tebu oleh penggiling merupakan kegiatan yang saling melengkapi. Usaha tani menghasilkan output berupa tebu yang menjadi input atau bahan baku bagi kegiatan penggiling. Selanjutnya, pengolahan tebu yang dilakukan oleh penggiling akan menghasilkan output berupa gula yang akan dijual oleh distributor ke konsumen akhir.

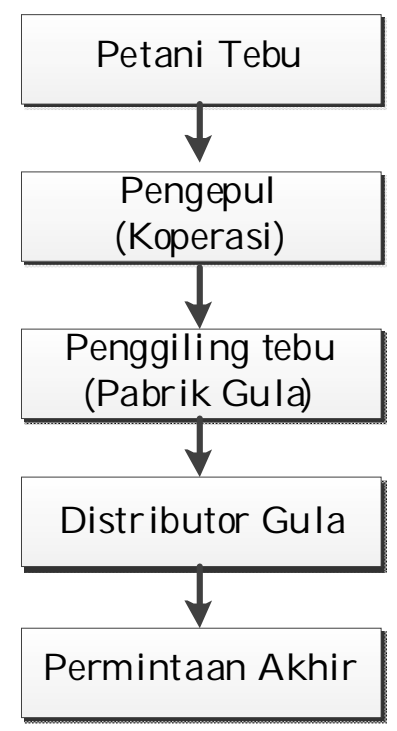

\section{Gambar 1. Jalur Distribusi Industri Gula}

Dari hasil pengolahan data diperoleh tabel input output jalur distribusi industri gula sebagai berikut: 
Tabel 2. Tabel Input Output Jalur Distribusi Industri Gula (Juta Rupiah)

\begin{tabular}{lcccccc}
\hline Onput & Petani & Pengepul & Penggiling & Distributor & Permt.akhir & $\begin{array}{c}\text { Total } \\
\text { output }\end{array}$ \\
\hline Petani & 0 & 584,64 & 0 & 0 & 0 & 584,64 \\
Pengepul & 0,1995 & 0 & 0,02585 & 0 & 0 & 0,22535 \\
Penggiling & 0 & 0 & 0 & 333,04 & 0 & 333,04 \\
Distributor & 0 & 0 & 0 & 0 & 380,1 & 380,1 \\
Nilai & 398,89 & 0 & 331,23 & 377,566 & & \\
Tambah & 399,0895 & 584,64 & 331,25585 & 710,606 & &
\end{tabular}

Tabel 2 di atas menunjukkan bahwa output dari kegiatan petani, yaitu tebu digunakan sebagai input untuk kegiatan pengepul sebesar 584,640 (juta rupiah), output dari kegiatan pengepul yaitu jasa sebagai pengepul tebu digunakan sebagai input untuk kegiatan petani dan penggiling masing-masing sebesar 0,1995 (juta rupiah) dan 0,02585 (juta rupiah), output dari kegiatan penggiling yaitu gula didistribusikan ke distributor gula sebesar 333,040 (juta rupiah), dan output darikegiatan distributor gula dijual ke konsumen akhir sebesar 380,100 (juta rupiah). Total output dari kegiatan petani, pengepul, penggiling dan distributor masing-masing adalah 584,640; 0,$22535 ; 333,040$ dan 380,100 (juta rupiah), sedangkan total input dari masing-masing kegiatan tersebut adalah 399,0895; 584,640; 331,25585 dan 710,606 (juta rupiah).

Sementara itu, indeks keterkaitan pada jalur distribusi industri gula adalah sebagai berikut: kata lain, kegiatan pengepul dan distributor ini memiliki daya penyebaran yang lebih tinggi terhadap kegiatankegiatan yang memberikan input bagi kegiatan pengepul dan distributor.

Sementara itu, kegiatan yang memiliki indeks keterkaitan ke belakang (Backward Linkages) dengan nilai kurang dari satu adalah kegiatan petani sebesar 0,7319 dan penggiling sebesar 0,7313 . Hal ini menunjukkan bahwa daya penyebaran dari kegiatan petani dan penggiling berada di bawah rata-rata penyebaran dari seluruh kegiatan yang menyumbangkan input untuk kegiatan-kegiatan tersebut. Dengan kata lain, kegiatan petani dan penggiling memiliki daya penyebaran yang rendah terhadap kegiatan-kegiatan lain yang memberikan input bagi kegiatan-kegiatan tersebut.

Analisis Keterkaitan ke Depan (Forward Linkages)

Dari tabel 3, diketahui bahwa kegiatan yang memiliki indeks keterkaitan ke depan (Forward

Tabel 3. Indeks Keterkaitan pada Jalur Distribusi Industri Gula

\begin{tabular}{lclc}
\hline Kegiatan & Forward Linkages & Kegiatan & Backward Linkages \\
\hline Petani & 1,4631 & Petani & 0,7319 \\
Pengepul & 0,7320 & Pengepul & 1,4630 \\
Penggiling & 1,0738 & Penggiling & 0,7313 \\
Distributor & 0,7311 & Distributor & 1,0739 \\
\hline
\end{tabular}

Analisis Keterkaitan ke Belakang (Backward Linkages)

Berdasarkan tabel 3 terlihat bahwa kegiatan yang mempunyai indeks keterkaitan ke belakang (Backward Linkages) yang bernilai lebih dari satu adalah kegiatan pengepul sebesar 1,4630 dan kegiatan distributor sebesar 1,0739. Hal ini menunjukkan bahwa dalam jalur distribusi industri gula ini, daya penyebaran dari kegiatan pengepul dan distributor di atas rata-rata penyebaran seluruh kegiatan yang menyumbang input pada kegiatan pengepul dan distributor tersebut. Dengan
Linkages) dengan nilai lebih dari satu adalah kegiatan petani sebesar 1,4631 dan kegiatan penggiling sebesar 1,0738. Hal ini berarti bahwa dalam jalur distribusi industri gula ini, daya kepekaan dari kegiatan petani dan penggiling di atas rata-rata dari kepekaan seluruh kegiatan yang menggunakan output dari kegiatankegiatan tersebut. Dengan kata lain, kegiatan petani dan penggiling tersebut memiliki daya kepekaan yang tinggi terhadap kegiatan-kegiatan lain yang membutuhkan input dari kegiatan tersebut. 
Sementara itu, kegiatan yang memiliki indeks keterkaitan ke depan (Forward Linkages) dengan nilai kurang dari satu adalah kegiatan pengepul sebesar 0,7320 dan distributor sebesar 0,7311. Hal ini menunjukkan bahwa daya kepekaan dari kegiatan pengepul dan distributor berada di bawah rata-rata kepekaan dari seluruh kegiatan yang membutuhkan input dari kegiatan-kegiatan tersebut. Dengan kata lain, kegiatan pengepul dan distributor memiliki daya kepekaan yang rendah terhadap kegiatan-kegiatan lain yang mendapatkan distribusi output dari kegiatan-kegiatan tersebut.

Plot Analisis Keterkaitan ke Belakang (Backward Linkages) dan Keterkaitan ke Depan (Forward Linkages)

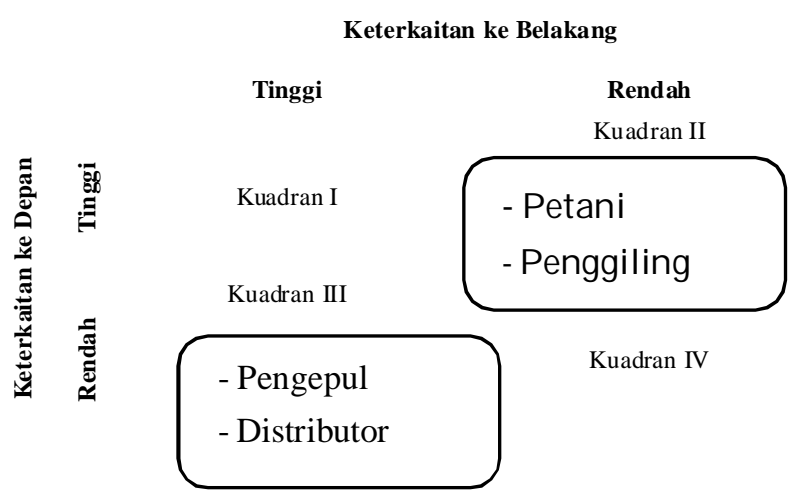

Gambar 2.Plot Analisis Keterkaitan ke Belakang (Backward Linkages) dan Keterkaitan ke Depan (Forward Linkages) Jalur Distribusi Industri Gula

Gambar 2 di atas menunjukkan bahwa pada jalur distribusi industri gula tidak ada kegiatan yang dapat menjadi sektor kunci (key sector) yang mampu menjadi penarik sekaligus sebagai pendorong bagi pertumbuhan kegiatan-kegiatan yang lain, karena pada kuadran I dapat dilihat bahwa tidak ada kegiatan yang memiliki keterkaitan ke belakang (Backward Linkages) dan keterkaitan ke depan (Forward Linkages) yang tinggi. Sementara itu, kuadran II diisi oleh kegiatan petani dan penggiling yang memiliki keterkaitan ke depan yang tinggi tetapi keterkaitan ke belakangnya rendah. Pengembangan dari sektor-sektor pada kuadran II ini akan mendorong tumbuhnya kegiatan yang ada di depannya namun kurang mampu untuk meningkatkan kegiatan yang ada di belakangnya. Kuadran III diisi oleh kegiatan pengepul dan distributor yang memiliki keterkaitan ke depan yang rendah sedangkan keterkaitan ke belakangnya tinggi. Pengembangan dari sektor-sektor pada kuadran III tersebut akan meningkatkan pertumbuhan kegiatan-kegiatan yang ada di belakangnya namun memiliki kemampuan lemah dalam meningkatkan kegiatan yang ada di depannya.

\section{KESIMPULAN DAN SARAN}

\section{Kesimpulan}

Dalam jalur distribusi industri gula, keterkaitan ke belakang (Backward Linkages) yang tinggi dimiliki oleh kegiatan pengepul dan distributor, sedangkan keterkaitan ke belakang (Backward Linkages) yang rendah dimiliki oleh kegiatan petani dan penggiling. Sementara itu, keterkaitan ke depan (Forward Linkages) yang tinggi dimiliki oleh kegiatan petani dan penggiling, sedangkan keterkaitan ke depan (Forward Linkages) yang rendah dimiliki oleh kegiatan pengepul dan distributor.

Tidak ada kegiatan yang memiliki keterkaitan ke belakang (Backward Linkages) dan keterkaitan ke depan (Forward Linkages) yang tinggi sehingga tidak ada kegiatan yang dapat menjadi sektor kunci (key sector) dalam jalur distribusi industri gula.

\section{Saran}

Metode input output yang digunakan dalam penelitian adalah analisis jalur distribusi untuk sesuatu yang spesifik, diharapkan penelitian berikutnya dapat menerapkan metode input output ini pada kasus yang lebih umum.

Dengan menggunakan metode input output ini, peneliti selanjutnya disarankan untuk menganalisis angka pengganda output, pendapatan rumah tangga dan lapangan pekerjaan dalam jalur distribusi.

\section{DAFTAR RUJUKAN}

Anonimus. 2012. Supply Chain, http://www.wikipedia.org (diakses 28 November 2012, pk 14:39 WIB).

Boediono. 1993. Ekonomi Makro. Yogyakarta. BPFE. Boediono, 1993 Boediono, 1993

Didit, P., dan Devi, I. 2008. Analisis Peranan Sektor Industri terhadap Perekonomian Jawa Tengah Tahun 2000 dan Tahun 2004 (Analisis Input-Output). Jurnal Ekonomi Pembangunan, Vol. 9, No. 2. Hal. 137-155.

Hermawan, W. 2006. Analisis Input Output Provinsi Jawa Barat. Majalah Ilmiah Bina Ekonomi, Vol. 10, No.1. Hal. 1-120.

Khudori. 2005. Gula Rasa Neoliberalisme: Pergumulan Empat Abad Industri Gula. Jakarta: Pustaka LP3ES Indonesia. 
Kula, M. 2008. Supply Use and Input-Output Tables, Backward and Forward Linkagesof The Turkish Economy. The 16th Inforum world Conference in Northern Cyprus. Istanbul. Turkey. 01-05 September.

Kuncoro, M. 2001. Metode Kuantitatif: Teori dan Aplikasi untuk Bisnis dan Ekonomi. Yogyakarta: AMPY KPN.

Leon, S.J. 1998. Aljabar Linear dan Aplikasinya. Edisi Kelima. Jakarta: Erlangga.

Nazara, S. 2005. Analisis Input-Output. Jakarta: Lembaga Penerbit FE UI.
Sumodiningrat, G., dan Kuntjoro, M. 1991. Ekonomi Pertanian di Indonesia: Perkembangan dan Peranan Modeling. Jakarta: Pusat Antar Universitas Studi Ekonomi-UI.

Wu, M. 2007. Topsis-AHP Simulation Model and Its Application to Supply ChainManagement. World Journal of Modelling and Simulation, Vol. 3, No. 3. pp. 196-201.

Zhou, M. 2011. Education and Management. Part III. NewYork: Springer. Verlag Berlin Heidelberg. 